\title{
Inventory, Conservation Statement and Classification of Bird Trade in Cianjur based on Data Mining Methods
}

\author{
Sri Wiedarti, Moerfiah, R P Zen, Fajar Delli Wihartiko
}

\begin{abstract}
Currently in the community many who keep birds. To get the birds people are looking for in the bird market. Total species of birds traded (Kabupaten Cianjur) as many as 46 types of 23 tribes. From the search results were found by IUCN endangered bird species but by law in Indonesia excluding protected ones such as the species of ekelgeling (Cissathalassina) whose conservation status is highly endangered. The excavation of the rule based on available data using the c45 algorithm shows that the dominance status of bird species in the Cipanas area has a significant influence on the status of the dominance of bird species for the entire Cianjur region.
\end{abstract}

\section{Index Terms: Conservation, Data Mining, C45.}

\section{INTRODUCTION}

Indonesia is home to $17 \%$ of the bird population on Earth, although it is only $1.3 \%$ of the land area. A sad note, many of the birds in Indonesia are dying. More than $20 \%$ of birds experience a population decline due to habitat loss, hunting and fishing for trading [1]. Some areas of Gede Pangrango Mountain National Park are located in Cianjur Regency. The number of bird species found in TNGGP of Cianjur Regency is 112 species from 32 tribes. Of all bird species, 14 species of which are endemic species of Java, 24 species protected by the government through Law No. 5/1990 and Government Regulation No. 7/1999.

The presence of bird demand by some communities becomes a market opportunity for traders and bird catchers to benefit economically. In meet the demand of birds then traders always try to provide birds for buyers. Efforts have been made to obtain the supply of birds so that traders and bird catchers often do not pay attention to threats to bird sustainability in nature [2]. Currently in the community many who keep birds because of hobbies and birds do have its own charm, because the voice is melodious, the color of the beautiful and attractive fur and his manner of fun. To get the birds people are looking for in the bird market. This is what prompted a study of bird species traded in the bird market in Cianjur regency to identify the diversity of bird species and protected and endangered bird species according to IUCN

Revised Manuscript Received on April 25, 2019.

Sri Wiedarti, Department of Biology, Universitas Pakuan, Indonesia.

Moerfiah, Department of Biology, Universitas Pakuan, Indonesia.

RP Zen, Department of Biology, Universitas Pakuan, Indonesia.

Fajar Delli Wihartiko, Department of Computer Science, Universitas Pakuan, Indonesia.
(International Union for Conservation of Nature) relist version 2016-2 and Government Regulation No.7 Year 1999.

The inventory data is then processed using the Knowledge Discovery (mining) in Databases (KDD). This is used to find a relationship or rule between available attributes. In determining the most influential attributes and rules search is done using the $\mathrm{C} 45$ algorithm.

\section{RESEARCH METHOD}

This research was conducted in bird market in Cianjur regency for 3 (three) months from August until October 2016. The materials used are birds in Bird Market in Cianjur regency. The tools used are GoPro Hero 3 cameras, handphone cameras, stationery, pocket books, Bird Manuals - Sumatran, Java, Bali, and Borneo (including Sabah, Sarawak and Brunei Darussalam) [3] and Guide to Birds [4]. The stages of research development are carried out using Knowledge Discovery (mining) in Databases (KDD) [5] as follows:

1. Data collection, data collection is done by the following process :

a. Direct observation at store of birds in Cianjur District, data collection is done from every store in each location taken two or three store to do observation.

b. The types of birds found are photographed or recorded with video formats. Then birds that have been recorded were identified by looking in Bird Birds - Bird watching guides in Sumatra, Java, Bali and Kalimantan (Including Sabah, Sarawak and Brunei Darussalam) [3] and Guide to Birds [4] as well as the internet.

c. Interviews with traders (questions that will be asked are on and interview to the community to know the linkage Bird Market with the bird keeper community.

2. Pre-processing data, the data pre-processing process is done by compiling numerical data into conservation based categorization from the 2016-2 IUCN Read list category and under Government Regulation No. 7 of 1999.

3. Data Mining, the process carried out is a rule search process for supervision data using the $\mathrm{C} 45$ algorithm. [6]

4. Pattern Evaluation, the evaluation process is done by looking at the accuracy of the training data used in the rule search.

5. Knowledge, the use of KDD results to be considered further.

In summary, the KDD process carried \&upecafnobeen in the following figure: 


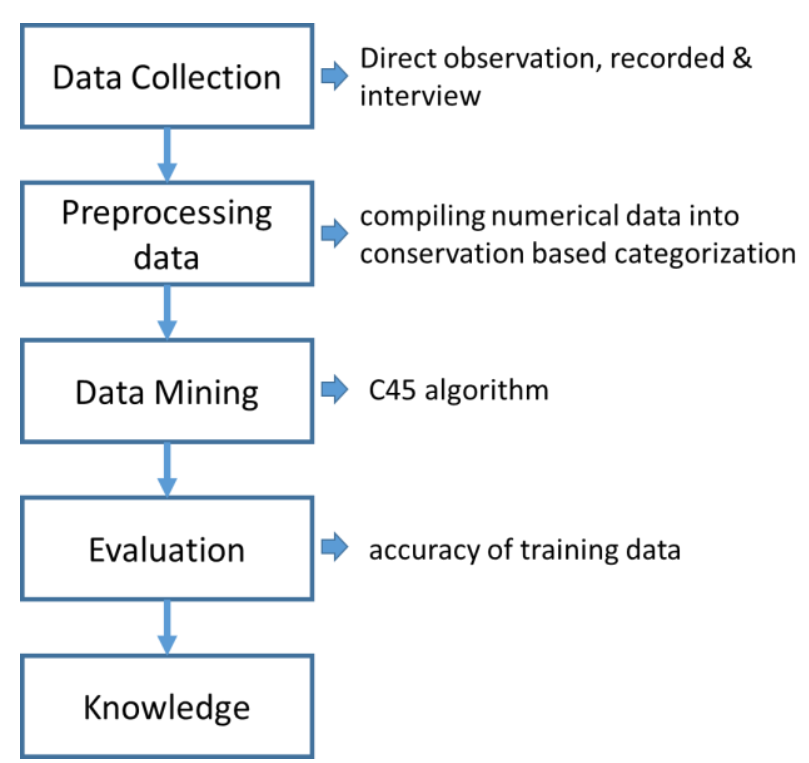

Fig. 1. Application of KDD on bird conservation data

\section{RESULT AND ANALYSIS}

Total species of birds found as many as 46 species from 23 tribes. The most common species in Cianjur are Javanese bondol (Lonchuraleucogastroides), walnut (Serinuscanaria), parakeet (Melopsittacusundulatus), ordinary glasses (Zosteropspalpebrosus) and lovebird (Agapornisfischeri). The list of number of bird species sold in Cianjur Regency can be seen in Table 1 .

Javanese bondol type (Lonchuraleucogastroides) is widely traded for crossbreeding with walnut so that the walnut's breeding results can have different colors [7]. From the results of interviews with traders can be known bird type lovebird is the most searched type of society and the most widely sold. The large number of lovebird species (Agapornisfischeri) traded because of this type of bird including easy breeding so that bird keepers can choose the chirp and color as desired. This kind of bird too the treatment is easy so that the fans grow more [8]. A pretty much sought-after bird is happening because of its melodious chirp and can slightly imitate other birds singing besides that this kind of bird can be eliminated so that the bird keepers try to get the superior bird with the rare color. While parakeet birds are much sought after because the tweet can trigger kikeun other types of birds to be better than that the parakeets have a variety of colors and can be invited to play when it is trained [9].

From the results of this study was obtained species of birds that are threatened with extinction according to IUCN. Of the three research sites, the species that belong to the category of endangered Java gelatik (Paddaoryzivora) are

Table 1. The Result of Data Collection

\begin{tabular}{|c|l|l|c|c|c|c|}
\hline \multirow{2}{*}{ No } & \multirow{2}{*}{ Species Name } & \multirow{2}{*}{ Scientific Name } & \multicolumn{3}{|c|}{ Location } & \multirow{2}{*}{ Sum } \\
\cline { 4 - 7 } & & & A & B & C & \\
\hline 1 & Anis Kembang & Zoothera interpres & & 6 & & 6 \\
\hline 2 & Anis Merah & Zoothera citrina & 2 & 6 & 2 & 10 \\
\hline 3 & Anis Siberia & Zoothera sibirica & 1 & & & 1 \\
\hline 4 & Bentet Kelabu & Lanius schach & 4 & 2 & 3 & 9 \\
\hline 5 & Bondol Jawa & $\begin{array}{l}\text { Lonchira } \\
\text { leucogastroides }\end{array}$ & & & 50 & 50 \\
\hline 6 & Burung Madu Pengantin & Nectarinia sperata & & 1 & & 1 \\
\hline 7 & Burung Madu Sriganti & Nectarinia jagularis & & & 4 & 4 \\
\hline 8 & Branjangan Jawa & Mirafra javanica & & 5 & & 5 \\
\hline 9 & Cica Daun Besar & Chloropsis sonnerati & 2 & 2 & & 4 \\
\hline 10 & Cica Daun Sayap Biru & Chloropsis & & & 2 & 2 \\
\hline
\end{tabular}

\begin{tabular}{|c|c|c|c|c|c|c|}
\hline & & cochinchinensis & & & & \\
\hline 11 & Cinenen Pisang & Orthotomus sutorius & & & 1 & 1 \\
\hline 12 & Cipoh Kacat & Aegithinia tiphia & 1 & 1 & 1 & 3 \\
\hline 13 & Cucak Kuning & $\begin{array}{l}\text { Pycnonotus } \\
\text { melanicterus }\end{array}$ & 1 & & 8 & 9 \\
\hline 14 & Cucak Kutilang & Pycnonotus aurigaster & 11 & & 8 & 19 \\
\hline 15 & Ekek Geling & Cissa thalassina & 1 & 1 & & 2 \\
\hline 16 & Empuloh Janggut & Alophoixus bres & & 1 & 2 & 3 \\
\hline 17 & Gelatik Batu Kelabu & Parus major & & & 2 & 2 \\
\hline 18 & Gelatik Jawa & Padda Oryzivora & & & 2 & 2 \\
\hline 19 & Jalak Suren & Sturnus contra & 2 & 2 & 2 & 6 \\
\hline 20 & Kacamata Biasa & Zosterops palpebrus & 10 & 2 & 12 & 24 \\
\hline 21 & Kacamata Jawa & Zosterops flavus & 2 & 3 & 2 & 7 \\
\hline 22 & Kaladi Ulam & Dendrocopus macei & & 1 & & 1 \\
\hline 23 & Kenari & Serinus canaria & 12 & 20 & 17 & 49 \\
\hline 24 & Kepudang Kuduk Hitam & Oriolus chinensis & 2 & & & 2 \\
\hline 25 & Kerak Kerbau & Acridotheres javanicus & 1 & & & 1 \\
\hline 26 & Kerak Ungu & Acridotheres tristis & & & 1 & 1 \\
\hline 27 & Kucica Hutan & Copsychus malabaricus & 3 & 1 & & 4 \\
\hline 28 & Kucica Kampung & Copsychus saularis & 1 & 2 & 2 & 5 \\
\hline 29 & Lovebird & Agapornis fischeri & 28 & 31 & 8 & 67 \\
\hline 30 & Merbah Cekukcuk & Pycnonotus goiavier & 10 & & 1 & 11 \\
\hline 31 & Merpati Batu & Columba livia & & & 2 & 2 \\
\hline 32 & Opior Jawa & $\begin{array}{l}\text { Lophozosterops } \\
\text { javanicus }\end{array}$ & & 2 & & 2 \\
\hline 33 & Palek Australia & Nymphicus hollandicus & 1 & 4 & & 5 \\
\hline 34 & Parkit & Melopsittacus undulatus & 20 & 2 & 2 & 24 \\
\hline 35 & Perenjak Coklat & Prinia polychroa & & & 8 & 8 \\
\hline 36 & Perenjak Jawa & Prinia familliaris & & 7 & 6 & 13 \\
\hline 37 & Perenjak Padi & Prinia inornata & & & 2 & 2 \\
\hline 38 & Perkutut Jawa & Geopelia striata & 10 & & 7 & 17 \\
\hline 39 & Pipit Zebra & Taeniopygia guttata & & 15 & & 15 \\
\hline 40 & Sikatan Bubik & Muscicapa dauurica & & 1 & & 1 \\
\hline 41 & Sikatan Ninon & Eumyias indigo & & & 1 & 1 \\
\hline 42 & Srigunting Hitam & Dicrurus macrocercus & 3 & & & 3 \\
\hline 43 & Takur Tulung Tumbuk & Psilopogan javensis & 1 & & & 1 \\
\hline 44 & Tekukur Biasa & Streptopelia chinensis & 1 & 1 & 1 & 3 \\
\hline 45 & Tepus Gelagah & Timalia pileata & & & 5 & 5 \\
\hline 46 & Tiong Emas & Gracula religiosa & 1 & 1 & & 2 \\
\hline \multicolumn{3}{|c|}{ Total } & 131 & 120 & 164 & 415 \\
\hline
\end{tabular}

Note : A = Cipanas; $\mathrm{B}=$ Cianjur City; $\mathrm{C}=$ Ciranjang

included in the category of VU (Vulnarable / vulnerable) and four types of birds that belong to the category of NT (Near Threatened / almost threatened) such as glasses of Java (Zosteropsflavus), lovebird (agapornisfischeri), stacked batches (Psilopogonjavensis) and flower anis (Zootherainterpres) as well as bird species categorized CR (Critically Endangered) ieekelgeling (Cissathalassina). Types that have a low risk of extinction or in the IUCN including the category of LC (Least concern) are the most widely found as many as 38 species. Meanwhile, there are 2 types that include DD (Data deficient / less data) that is the type of buffalo crust (Acridotheresjavanicus) and Javanese koput (Geopeliastriata). The lack of data on the IUCN is due to the lack of research for the species. List of conservation status of types - types of birds traded inCianjur District can be seen on Table 2 (Preprocessing result).

In this study found bird species protected according to Indonesian legislation listed in Government Regulation No. 7 of 1999 such as birds of honey bride (Nectariniasperata), sriganti honey (Nectariniajagularis), tiong gold (Graculareligiosa) and stacked bushes (Psilopogonjavensis). From the search results were found by IUCN endangered bird species but by law in Indonesia excluding those protected for the species of ekelgeling (Cissathalassina) whose conservation status is highly endangered.

The prohibition of catching, buying and sustaining honey-birds is not due to the fact that the population in the wild is diminishing. This bird is protectedfor its vital role in the natural pollination process of parants Enproforests and plantations. Because the populafity of birds ehirping competitions in bird-honey colibritclasses is even more and 
more easily found in the bird market. The huge potential benefits derived from wildlife trade, especially rare animals, have encouraged increased animal trade activities. The wildlife traders continue to catch and hunt wildlife from the wild which is then traded illegally by them. In addition to being trafficked, people exploit and exploit natural resources, especially animals for their livelihood. [10] The fulfillment of the necessities of life is gradually done with no heed of ecosystem and ecological sustainability when all these needs have become a material demand that must be met.

The results of applying the C45 algorithm in Table 2 show that there is no relationship between conservation status and bird data sold. Trees that can be formed are generated based on dominance status in each market towards the whole Cianjur region. Trees formed can be seen in Figure 2 with an accuracy of $67.4 \%$.Cipanas Market affects the status of conservation domination for the Cianjur region as a whole. The rules that are formed are if the status of Cipanas is not dominated, then the status of Cianjur is also not dominance. If the status of Cipanas subdominant, the status of cianjur is not dominated and if the status of Cipanas is dominated, then the status of Cianjur is also dominated.

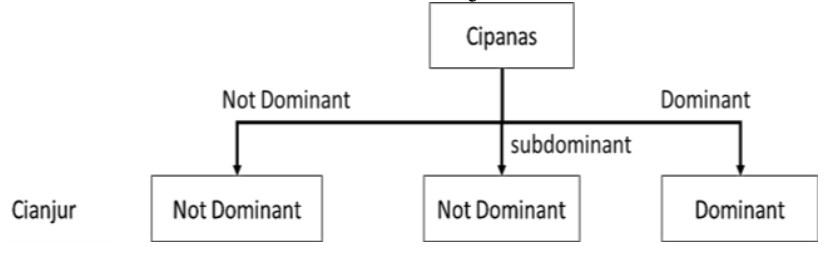

Fig. 2. Tree from Table 2 by c45 Algorithm

\section{CONCLUSION}

From this research can be concluded:

1. Number of bird species found as many as 46 species from 23 tribes. The most common species in Cianjur regency are Javanese bondol (Lonchuraleucogastroides), walnut (Serinuscanaria), parakeet (Melopsittacusundulatus), ordinary glasses (Zosteropspalpebrosus) and lovebird (Agapornisfischeri)

Table 2. The Result of Preprocessing data

\begin{tabular}{|c|c|c|c|c|c|c|}
\hline \multirow{2}{*}{ No } & \multirow{2}{*}{ Species Name } & \multicolumn{4}{|c|}{ Location } & \multirow{2}{*}{ Status } \\
\hline & & $\mathbf{A}$ & B & C & Cianjur & \\
\hline 1 & Anis Kembang & ND & $\mathrm{D}$ & ND & ND & Near Threatened \\
\hline 2 & Anis Merah & ND & $\mathrm{D}$ & ND & Sub & Least Concern \\
\hline 3 & Anis Siberia & ND & ND & ND & ND & Least Concern \\
\hline 4 & Bentet Kelabu & Sub & ND & ND & Sub & Least Concern \\
\hline 5 & Bondol Jawa & ND & ND & $\mathrm{D}$ & $\mathrm{D}$ & Least Concern \\
\hline 6 & Burung Madu Pengantin & ND & ND & ND & ND & Least Concern \\
\hline 7 & Burung Madu Sriganti & ND & ND & Sub & ND & Least Concern \\
\hline 8 & Branjangan Jawa & ND & Sub & ND & ND & Least Concern \\
\hline 9 & Cica Daun Besar & ND & ND & ND & ND & Least Concern \\
\hline 10 & Cica Daun Sayap Biru & ND & ND & ND & ND & Least Concern \\
\hline 11 & Cinenen Pisang & ND & ND & ND & ND & Least Concern \\
\hline 12 & Cipoh Kacat & ND & ND & ND & ND & Least Concern \\
\hline 13 & Cucak Kuning & ND & ND & Sub & Sub & Least Concern \\
\hline 14 & Cucak Kutilang & $\mathrm{D}$ & ND & Sub & Sub & Least Concern \\
\hline 15 & Ekek Geling & ND & ND & ND & ND & Critically Endangered \\
\hline 16 & Empuloh Janggut & ND & ND & ND & ND & Least Concern \\
\hline 17 & Gelatik Batu Kelabu & ND & ND & ND & ND & Least Concern \\
\hline 18 & Gelatik Jawa & ND & ND & ND & ND & Vulnerable \\
\hline 19 & Jalak Suren & ND & ND & ND & ND & Least Concern \\
\hline 20 & Kacamata Biasa & $\mathrm{D}$ & ND & $\mathrm{D}$ & $\mathrm{D}$ & Least Concern \\
\hline 21 & Kacamata Jawa & ND & Sub & ND & ND & Near Threatened \\
\hline 22 & Kaladi Ulam & ND & ND & ND & ND & Least Concern \\
\hline 23 & Kenari & $\mathrm{D}$ & $\mathrm{D}$ & $\mathrm{D}$ & $\mathrm{D}$ & Least Concern \\
\hline 24 & Kepudang Kuduk Hitam & ND & ND & ND & ND & Least Concern \\
\hline 25 & Kerak Kerbau & ND & ND & ND & ND & Data Deficient \\
\hline 26 & Kerak Ungu & ND & ND & ND & ND & Least Concern \\
\hline 27 & Kucica Hutan & Sub & ND & ND & ND & Least Concern \\
\hline 28 & Kucica Kampung & ND & ND & ND & ND & Least Concern \\
\hline
\end{tabular}

\begin{tabular}{|c|l|c|c|c|c|c|}
\hline 29 & Lovebird & D & D & Sub & D & Near Threatened \\
\hline 30 & Merbah Cekukcuk & D & ND & ND & Sub & Least Concern \\
\hline 31 & Merpati Batu & ND & ND & ND & ND & Least Concern \\
\hline 32 & Opior Jawa & ND & ND & ND & ND & Least Concern \\
\hline 33 & Palek Australia & ND & Sub & ND & ND & Least Concern \\
\hline 34 & Parkit & D & ND & ND & D & Least Concern \\
\hline 35 & Perenjak Coklat & ND & ND & Sub & ND & Least Concern \\
\hline 36 & Perenjak Jawa & ND & D & Sub & Sub & Least Concern \\
\hline 37 & Perenjak Padi & ND & ND & ND & ND & Least Concern \\
\hline 38 & Perkutut Jawa & D & ND & Sub & Sub & Data Deficient \\
\hline 39 & Pipit Zebra & ND & D & ND & Sub & Least Concern \\
\hline 40 & Sikatan Bubik & ND & ND & ND & ND & Least Concern \\
\hline 41 & Sikatan Ninon & ND & ND & ND & ND & Least Concern \\
\hline 42 & Srigunting Hitam & Sub & ND & ND & ND & Least Concern \\
\hline 43 & Takur Tulung Tumbuk & ND & ND & ND & ND & Near Threatened \\
\hline 44 & Tekukur Biasa & ND & ND & ND & ND & Least Concern \\
\hline 45 & Tepus Gelagah & ND & ND & Sub & ND & Least Concern \\
\hline 46 & Tiong Emas & ND & ND & ND & ND & Least Concern \\
\hline
\end{tabular}

Note $: \mathrm{A}=$ Cipanas $; \mathrm{B}=$ Cianjur City $; \mathrm{C}=$ Ciranjang; $\mathrm{ND}=$ Not Dominant; sub = subdominant $\mathrm{D}=$ Dominant

2. There are endangered species according to IUCN. Types that are included in the category of endangered Java gelatik (Paddaoryzivora) are included in the category of VU (Vulnarable / vulnerable), category NT (Near Threatened / almost threatened) such as glasses of Java (Zosteropsflavus), love bird (Agapornisfischeri), (Psilopogonjavensis) and flower anis (Zootherainterpres) and CR category (Critically Endangered), which is ekek geling (Cissathalassina).

3. There are species of birds protected in Indonesian legislation PP No.7 Year 1999 such as birds of honey bride (Nectariniasperata), sriganti honey (Nectariniajagularis), tiong of gold (Graculareligiosa) and stack of tulung (Psilopogonjavensis).

4. There is no relationship between conservation status based on IUCN and the dominance of bird species on the market. Cipanas market is the most dominant attribute affecting conditions in the entire Cianjur market as a whole with an accuracy rate of $67.4 \%$.

\section{REFERENCES}

1. M. Strange. A photographic guide to the birds of Indonesia. New Jersey: Princeton University Press, 2001

2. T. Haryoko. "Komposisi jenis dan jumlah burung liar yang diperdagangkan dijawa barat. Berita biologi," vol. 10, no. 3, pp. 385-391, 2010.

3. J. MacKinnon, K. Philips and B. Van Balen. Burung-burung di Sumatera, Jawa, Bali dan Kalimantan (termasuk sabah, Serawak dan Brunei Darussalam). Jakarta: Puslitbang Biologi-LIPI dan Birdlife International -Indonesian Programme, 1991.

4. D. Sibley, C. Elphick and J. B. Dunning. The Sibley guide to bird life \& behavior. New York: National Audubon Society, 2001.

5. J. Han, J. Pei and M. Kamber. Data mining: concepts and techniques. Amsterdam: Elsevier, 2011.

6. S. L. Salzberg, "C4. 5: Programs for machine learning by j. ross quinlan. morgan kaufmann publishers." Machine Learning, vol. 16, no. 3, pp. 235-240, 1994. III

7. Sridadi. Beternak Blackthroat dan Permasalahannya. Yogyakarta: Kanisius Publisher, 2002.

8. H. Biantono and R. Setiawan. Sukses Menagkarkan dan Memelihara Lovebird. Jakarta: Penebar Swaday, 2013.

9. R. Turut. Burung Ocehan Juara Kontes. Jakarta: Penebar Swadaya Grup, 2012.

S Wiedarti, Moerfiah ,Cecep Sudrajat Galih Muhamad Iqbal. The Diversity of Bird Species that are Traded in the Bird Market in the City of Bogor, Indonesia. AIP Conference Proceedings 1744, 020056 (2016); https://doi.org/10.1063/1.4953530 